\title{
Empirical Examination of Market Reaction to Transfer Pricing Taxation Announcement in Press: A Japanese Perspective*
}

\author{
Hiroshi Ohnuma \\ Tokyo University of Science, Tokyo, Japan \\ Keikichi Kato \\ Hirosaki University, Hirosaki, Japan
}

\begin{abstract}
The Japanese Taxation Agency (JTA) introduced transfer pricing taxation (TPT) in order to suppress the outflow of profits and therefore taxes of Japanese companies, which are expanding overseas. There have been many press reports regarding the application of TPT, and so there is much public attention on this issue. TPT is applied to unnatural transfer prices (TP). If TPT is applied to a multinational company (MNC), the company will need to bear enormous documentation costs in its calculation of the ratable price. In addition, in the last few years, the target of TPT is shifting to the overseas transfer of intangible assets, such as trademarks, royalties, patents, and charges income. As a result, companies have become more careful about TPT and investors tend to pay attention to companies' TPT strategy. With regard to this point, this paper examines how the market evaluates news regarding TP by investigating the market reaction to an initial press report mentioning that a firm was involved in a TP manipulation and may be guilty of tax underpayment. We examine these events both because press reports are currently under intense scrutiny and because there has been very little research on firms that engage in tax sheltering (see, e.g., Graham \& Tucker, 2006; Hanlon \& Slemrod, 2009). Some view the fact that not all firms engage in tax sheltering as surprising because of the widespread view that shelters, at least in the 1990s, in expectation, offered a positive net present value position. The potential negative public relations effect is often cited as one reason for this "under-sheltering" phenomenon (Bankman, 2004). On the event study analysis, we find that the Japanese capital market has shown a statistically significant negative reaction to the press reports. This result is due to a strong distrust of corporate activity regarding TP strategies. Moreover, in order to clarify the reason why the market responds to reports of TPT being applied, we compute the cumulative abnormal returns (CARs) around the date of the press report and conduct two-stage least-squares estimation to examine where this result regarding the market reaction comes from. Our results indicate that the variables for intangible assets and effective tax rate and the variables which represent the extent of corporate governance (CG) are statistically significant with respect to these reactions.
\end{abstract}

Keywords: tax management, tax avoidance, transfer pricing taxation (TPT), event study, intangible assets, corporate governance (CG)

\footnotetext{
* Acknowledgment: Ohnuma and Kato would like to thank financial support from the Japanese Society for the Promotion of Science, Grant-in-Aid for Scientific Research (C) 22530494.

Hiroshi Ohnuma, associate professor, School of Management, Tokyo University of Science. Email: hiroshi_onuma@rs.tus.ac.jp.

Keikichi Kato, professor, Faculty of Humanities, Hirosaki University.
} 


\section{Introduction}

As far as the many companies which aim to go abroad (usually referred to as multinational companies (MNCs)) are concerned, light taxation countries are the most advantageous locations for companies with high corporate taxes. From the viewpoint of MNC's transfer prices (TP), Tang (1992) explained how the TP is set. According to this study, the TP is set based on "the company-wide profit maximization strategy" and it is adjusted in consideration of the "difference between the corporate tax rate of each country and the Japanese corporate tax system" (p. 89). Prior studies note that the main factor is the difference between the domestic corporate tax rate and the foreign tax rate when an MNC sets the TP. On the other hand, since the Japanese government purports to be in favor of the suppression of overseas outflow of domestic income, in order to cope with this MNC TP strategy, the Japanese Taxation Agency (JTA) has introduced transfer pricing taxation (TPT) and taken a legally strict approach to the tax returns of foreign income for a quarter century. ${ }^{1}$

There is currently a high degree of public attention paid to newspaper reports about the application of TPT. TPT is applied to unnatural TP. If the tax authority takes affirmative steps and enforcement measures to apply TPT to an MNC, the company will need to bear enormous documentation costs in its calculation of the ratable price. In addition, in the last few years, the target of TPT is shifting from the overseas transfer of tangible assets, such as inventories, property, plant, and equipment, to intangible assets such as trademarks, royalties, patents, and charges income. As a result, companies have become more careful about TPT and investors tend to pay attention to companies' TPT strategy.

This paper examines how the market evaluates news regarding TP by investigating the market reaction to an initial press report mentioning that a firm was involved in a TP manipulation and may be guilty of tax underpayment. We examine these events both because press reports are currently under intense scrutiny and because there has been very little research on firms that engage in tax sheltering (see, e.g., Graham \& Tucker, 2006; Hanlon \& Slemrod, 2009). Some view the fact that not all firms engage in tax sheltering as surprising because of the widespread view that shelters, at least in the 1990s, in expectation, offered a positive net present value position. The potential negative public relations effect is often cited as one reason for this "under-sheltering" phenomenon (Bankman, 2004). We construct our sample by searching for press articles, announcements, and newswire reports for the term "transfer price" along with either "corporate" or "corporation", and then restrict the sample to cases where the news refers to some type of accusation or announcement in the press that the firm engaged in TP-related tax avoidance or tax aggressiveness. We find that the capital market shows a statistically significantly negative reaction to newspaper reports of TPT. This result is due to a strong distrust of corporate activity regarding TP strategies.

Next, after an event study analysis, we carry out a multiple regression analysis to obtain abnormal returns (ARs). Then, these daily ARs are summed to obtain the cumulative abnormal return (CAR) for a given time period. As a result, we find that intangible assets and the corporate effective tax rate and variables related to corporate governance $(\mathrm{CG})$ are statistically significant with respect to the market reaction.

The remainder of the paper is as follows. Section 2 explains TPT. Section 3 presents the event study and Section 4 constructs the research hypotheses in this study. Section 5 describes the cross-sectional analysis that is the main analysis of this report. Section 6 explains the results of our analysis. Section 7 presents conclusions and suggestions for future research.

\footnotetext{
${ }^{1}$ A similar result holds for the 2000s since Tang (1992) and Lee and Joso (2009).
} 


\section{TPT}

\section{Overview of TPT in Japan}

The JTA has introduced TPT in order to cope with international tax avoidance since the passing of the tax reform act of 1986 in Japan. In terms of trading with related foreign companies, TPT is taxed according to the price when there is a transaction price among comparable non-related enterprises.

TP with comparable non-related enterprises is called an "arm's length price". The method of arm's length price setting in Japan has been decided according to sales, purchases, and other dealings involving inventory turnover. The setting of TP in Japan is based on three basic methods: the comparable uncontrolled price method (method based on the price of the transaction among comparable non-related companies), the resale price method (method of calculating and deducting the amount of usual profit from the resale price among related industries), and the cost plus method (method of adding the usual profit to the seller's cost in dealings among related companies). In addition to the three methods above, JTA established the fourth method (which allows calculation by, for instance, the profit split method or the transactional net margin method (TNMM)).

\section{Recent Trends in TPT}

A quarter century has passed since TPT began to be enforced in Japan and many issues have been pointed out regarding the calculation of TP. These issues are mainly concerned with the incompatibility of the TP calculation method itself and the intangible assets problem. Recently, the business community has become so complicated because of globalization that the objective of the TP has expanded from tangible assets, referred to as products and inventory, to intangibles, including patent rights, trademarks, technology transfers, product development, management know-how, and service rendering. However, the TP calculation of intangibles is complex and does not match the three basic TP calculation methods. Because the original characteristic of intangibles is that "the difference with others is accepted monopolistically", it is natural that it is difficult to compare prices of intangibles among independent companies. Thus, JTA began to use alternative TP calculation methods, referred to collectively as "the fourth method".

Furthermore, due to different ideas regarding the calculation of TP, cases of double taxation, additional taxes, and tax suits between companies and JTA increased. JTA created the "Advance Pricing Agreement (APA) $)^{2 "}$ and the "Mutual Agreement Procedure (MAP)" regarding TP in order to reduce the risk of double taxation, but this was not sufficient to address the problem. According to JTA (2013), 167 MAP cases occurred in 2012 (of which 131 cases involved APA). In comparison with 2001, this is a 1.8-fold increase in MAP and an approximately 2.8-fold increase in MAP related to APA over the 10 years.

MAP cases (see Figure 1) break down into inventory trading cases (108), service rendering cases (66), and intangibles trading cases (66).

The TNMM prescribed as an "alternate method" introduced by the tax reform of 2004 became the main method of TP calculation in cases involving the MAP (see Figure 2). In other words, it became clear that the TP calculation methods referred to as the three basic methods could not cope with TP calculation of service rendering and intangibles trades. Therefore, intangibles have had a large influence on TPT practices. ${ }^{4}$

\footnotetext{
${ }^{2}$ APA is an administrative approach that attempts to prevent TP disputes from arising by determining criteria for applying the arm's length principle to transactions in advance of the occurrences of those transactions.

3 The MAP serves to prevent taxation which is not in accordance with the Double Taxation Agreement through actions by the contracting countries.

${ }^{4}$ TNMM is a method for calculating TP in comparison with the comparison company from the operating profit ratio and the mark-up rate for total cost.
} 


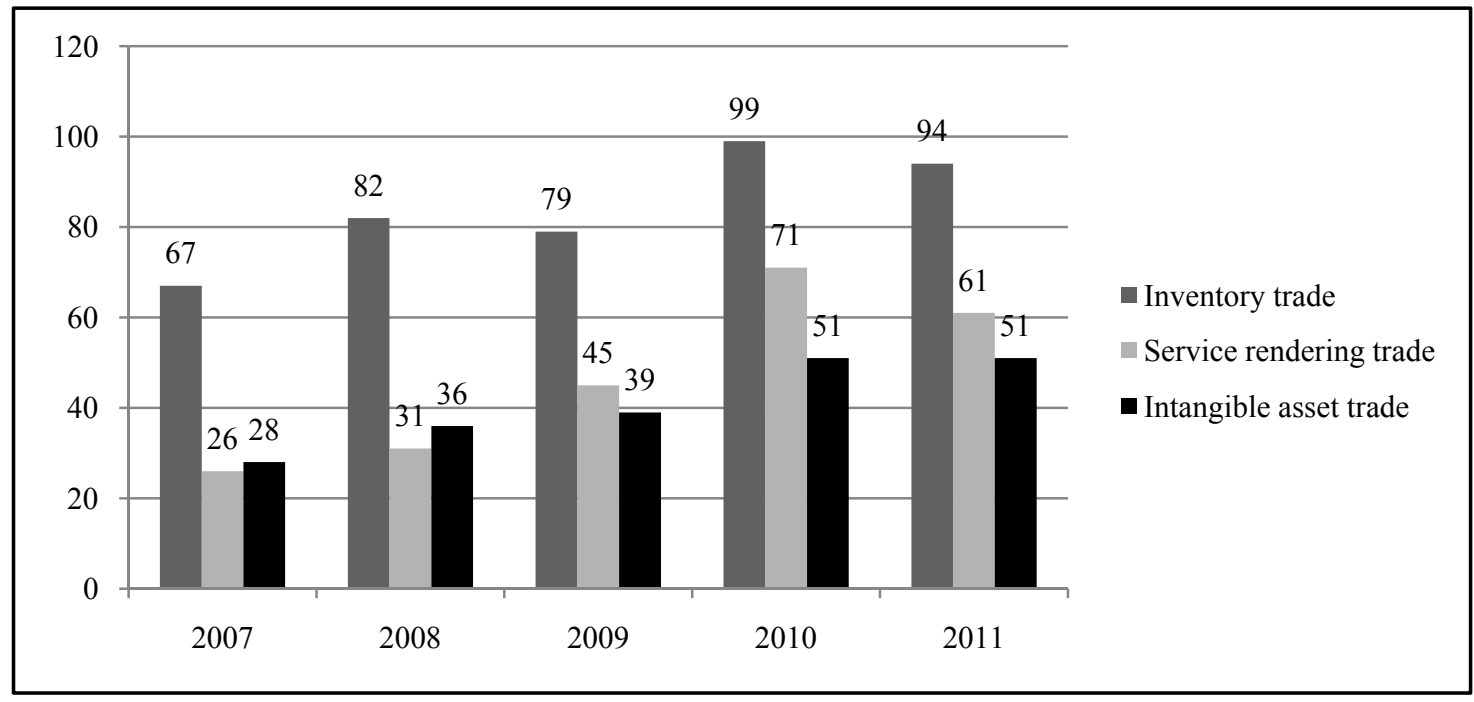

Figure 1. Breakdown according to TP trade under MAP. Source: JTA (2013).

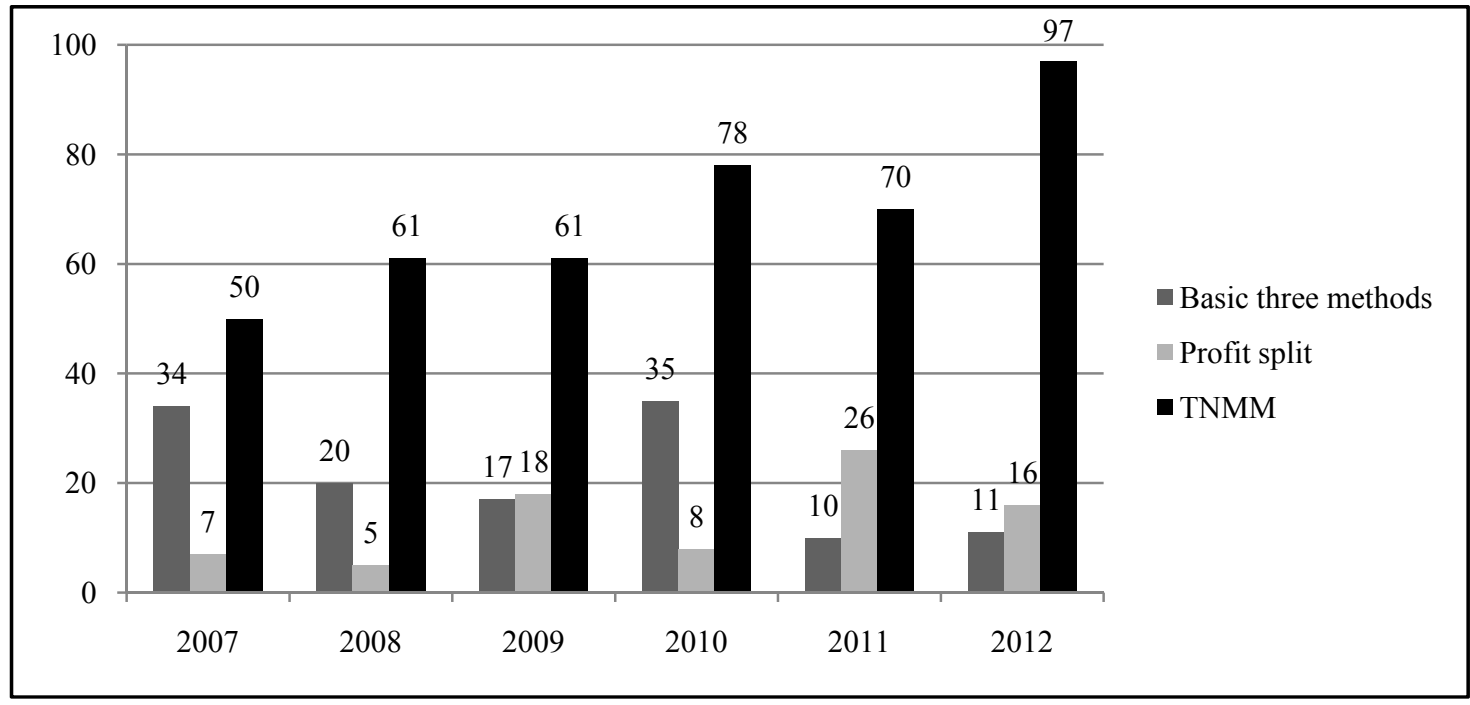

Figure 2. Breakdown according to the type of TP calculation method under MAP. Source: JTA (2013).

\section{Prior Studies}

There are considerable literatures that use event study methodology to examine the effects on stock market value of information revealed about corporate misdeeds other than tax noncompliance.

Campbell, Gordon, Loeb, and Zhou (2003) examined the economic effect of information security breaches reported in newspapers on publicly traded US corporations. They found limited evidence of an overall negative stock market reaction to public announcements of information security breaches. However, further investigation reveals that the nature of the breach affects this result. They found a significantly negative market reaction for information security breaches involving unauthorized access to confidential data, but no significant reaction when the breach does not involve confidential information. Thus, stock market participants appear to discriminate across types of breaches when assessing their economic impact on affected firms. These findings are consistent with the argument that the economic consequences of information security breaches vary with respect to the nature of the underlying assets affected by the breach. 
Croyd, Mills, and Weaver (2003) analyzed the statistical significance of each corporate inverting firm's ARs around the date that it initially announced its intentions and board of director approval of an inversion transaction. In this research, they mainly focused on US corporations that reorganize in tax-haven countries and claim to save many millions of dollars in future US corporate income taxes. However, because these "inversion" transactions may involve significant nontax costs, it is not obvious how they affect share value. They found that five of the 20 single-company expatriations in their analysis have significant negative announcement period returns and only two show significant positive returns. The remaining 13 inversions show no statistically significant market reaction in the announcement period. The average return in the announcement period across all 20 firms is negative, but not significantly different from zero. Overall, this article does not detect obvious shareholder benefits from expatriations.

Cavusoglu, Mishra, and Raghunathan (2004) examined the impact of security breaches on the market value of breached firms using an event study analysis and market valuations. The results show that announcing an internet security breach is negatively associated with the market value of the announcing firm. The breached firms in the sample lost, on average, $2.1 \%$ of their market value within two days of the announcement - an average loss in market capitalization of $\$ 1.65$ billion per breach. Firm type, firm size, and the year the breach occurred help explain the cross-sectional variations in ARs produced by security breaches. The effects of security breaches were not restricted to the breached firms. The market value of security technology firms was positively associated with the disclosure of a security breach. The security firms in the sample realized, on average, an AR of $1.36 \%$ within two days after the announcement. This produced, on average, a total gain for security firms of $\$ 1.06$ billion in a two-day period.

Hanlon and Slemrod (2009) analyzed what kind of influence that news releases about international tax avoidance involving TPT had on investor actions. They found that the reaction of investors is significantly negative for the news releases about companies using tax sheltering, that is, they found that, on average, a company's stock price declines when there is news about the company's involvement in tax sheltering. ${ }^{5}$

Armstrong, Barth, Jagolinzer, and Riedl (2010) examined European stock market reactions to 16 events associated with the adoption of International Financial Reporting Standards (IFRS) in Europe. European IFRS adoption represented a major milestone towards financial reporting convergence yet spurred controversy reaching the highest levels of government. They found an incrementally positive reaction for firms with lower-quality pre-adoption information, which is more pronounced for banks, and with higher pre-adoption information asymmetry, consistent with investors expecting net information quality benefits from IFRS adoption. Besides, they found an incrementally negative reaction for firms domiciled in code law countries, consistent with investors' concerns over the enforcement of IFRS in those countries. Finally, Armstrong et al. (2010) found a positive reaction to IFRS adoption events for firms with high-quality pre-adoption information, consistent with investors expecting net convergence benefits from IFRS adoption.

Gatzlaff and McCullough (2010) examined the stock market's assessment of the cost of data breaches at publicly traded companies in which personal information, such as customer and/or employee data, is exposed. Using event study methodology on a sample of 77 events between the beginning of 2004 and the end of 2006, they found that the overall effect of a data breach on shareholder wealth is negative and statistically significant.

\footnotetext{
${ }^{5}$ Rent extraction means the action of monopolizing profit by means of possessing information. In this case, even if a manager monopolizes profit based on a complicated tax avoidance method, it is difficult for the details to be known to a stockholder and, as a result, will raise agency cost (see S. Chen, X. Chen, Cheng, \& Shevlin, 2010; Desai \& Dharmapala, 2006).
} 
Based on a cross-sectional analysis of the CARs, they found a negative association between market reaction and firms that are less forthcoming about the details of the breach. They also found that firms with higher market-to-book ratios experience greater negative ARs associated with a data breach. Further, Gatzlaff and McCullough (2010) found that firm size and subsidiary status mitigate the negative effect of a data breach on the firm's stock price and that the negative market reaction to a data breach is more significant in the most recent time periods of the sample.

Ghosh, Giambona, Harding, Sezer, and Sirmans (2010) examined the role of stock option programs and executive holdings of stock options in real estate investment trust (REIT) governance. They investigated the role that stock option programs and other internal governance mechanisms play in overall REIT governance by analyzing how these factors influence the market reaction to the announcement of a stock repurchase. In particular, they examined how executive and employee stock option holdings influence the market reaction to a firm's announcement of a stock repurchase. Using a sample of REIT repurchase announcements, Ghosh et al. (2010) found that the market reacts more favorably to announcements by firms where executives have larger option holdings and the chief executive officer is not entrenched. Their results with respect to the roles of stock option holdings of executives and non-executives differ from those reported for a cross-section of non-REIT firms. Though they found evidence supporting the importance of executive stock options in aligning the incentives of management and reinforcing the positive signaling associated with a repurchase announcement, they found little evidence that the market views REIT repurchases as being used primarily to fund option exercise.

While there are few previous analyses of the stock market reaction to tax sheltering, there are several studies related to tax avoidance and CG. Desai and Dharmapala (2006) examined how investors value managerial actions designed solely to minimize corporate tax obligations by regressing over a cross-section of companies' Tobin's $q$ (market value divided by the replacement cost of assets) on a proxy for tax avoidance (measured as an estimate of the book-tax differences of the firm less an estimate of the portion of the book-tax differences due to earnings management, i.e., the total accruals of the firm). They found that their proxy for tax avoidance is positively related to firm value for well-governed firms, but weakly related to firm value for poorly-governed firms. The authors interpret their evidence as consistent with agency costs mitigating the benefits to shareholders of corporate tax avoidance. In other words, the managers' tax sheltering decisions are related to their ability to divert value, so that in poorly-governed firms, tax sheltering is indicative of a higher likelihood of managerial wealth diversion, and thus on net adds no value.

Graham and Tucker (2006) investigated a sample of 44 firms that received a notice of deficiency from the Internal Revenue Service (IRS) for their involvement in a tax shelter to determine whether the firm's tax shelter acted as a non-debt tax shield. They found that the tax-sheltering firms do appear to carry less debt during the years in which the tax shelter is in place (as well as the years leading up to the shelter years). Graham and Tucker (2006) did not, though, investigate the market's response to news of these shelters.

Onuma (2011) focused on 28 examples of companies that disclosed information voluntarily for a capital market about TPT from 2000 to 2010 and clarified the reactions of investors in the capital market by an event study statistical analysis. Onuma (2011) found that although the reactions are not strong, investors react to CAR from a voluntary information disclosure in a statistically significant manner on the event day and for six business days after. 
Kato (2011) paid attention to five news reports of TPT being applied to royalty fees of intangibles recognized on the balance sheet. Using the event study methodology from 2004 to 2008, Kato (2011) found a statistically significant negative reaction before a newspaper release about CAR taking place from the day of information disclosure (event day) to the following day.

Therefore, this article elaborates the reaction of investors to news reports about the application of TPT, based on Onuma (2011) and Kato (2011). Basically, while this paper is based on Onuma (2011), we use a significantly larger sample than ever. ${ }^{6}$

\section{Influence on the Stock Market of TPT News}

\section{Details of the Event Study}

We use an event study methodology to test the market reaction to the news that TPT has been applied to a company. We label the day that TPT news appeared in the press as the event day. The estimated period is $-180-30$ days, that is, the 150 days before the event day.

News reports regarding TPT were collected from the databases "Nikkei Telecom" (Nikkei Media Marketing), "Yomidasu" (Yomiuri Newspaper), and "Asahi-Kikuzo II" (Asahi Newspaper). We count as one case if our searches turned up hits regarding TPT in all three databases. After the TPT enforcement of 1986, we chose 51 of 78 cases (those for which we could get stock price data) that included news of TPT being applied. Finally, we excluded one company from the analysis because that company no long exists and was unlisted from the stock market at the time of the news release, giving a set of 50 cases for analysis.

To test the market reaction to the TPT news, we use the three-factor models about stocks proposed by Fama and French (1992) (see Equation (1)):

$$
R_{i, t}-R_{f, t}=a_{i}+b_{i}\left(R_{m, t}-R_{f, t}\right)+s_{i} S M B_{t}+h_{i} H M L_{t}+e_{i, t}
$$

where $R_{i, t}$ is the return of stock $i$ on day $t ; R_{f, t}$ is the risk-free rate; $R_{m, t}$ represents the return on the Tokyo Stock Market portfolio on day $t$; SMB is the "Small Minus Big" market capitalization risk factor; and $H M L$ is the "High Minus Low" value premium risk factor. In this model, SMB measures the additional return that investors have historically received by investing in stocks of companies with relatively small market capitalization. This additional return is often referred to as the "size premium". $H M L$ has been constructed to measure the "value premium" provided to investors for investing in companies with high book-to-market values (essentially the value placed on the company by accountants as a ratio relative to the value the public markets placed on the company). The key point of the model is that it allows investors to weight their portfolios so that they have greater or lesser exposure to each of the specific risk factors, and therefore can target more precisely different levels of expected return; $a_{i}, b_{i}, s_{i}$, and $h_{i}$ stand for the intercept and slope parameters, respectively, for firm $i$; and $e_{i, t}$ symbolizes a disturbance term for stock $i$ on day $t$, with the usual ordinary least squares (OLS) properties (Sharma $\&$ Mehta, 2013). In order to obtain AR for firm $i$ on day $t$, we perform regression estimates of $a_{i}, b_{i}, s_{i}$, and $h_{i}$ individually using Equation (1) and then apply the estimates to Equation (2) for each company:

$$
A R_{i, t}=R_{i, t}-R_{f, t}-\hat{a}_{i}-\hat{b}_{i}\left(R_{m, t}-R_{f, t}\right)-\hat{s}_{i} S M B_{t}-\hat{h}_{i} H M L_{t}
$$

\footnotetext{
${ }^{6}$ It is well known that the three-factor models of Fama and French (1992) can explain the price earnings ratio from market beta, aggregate market value, and the book value/aggregate market value ratio.
} 
In addition to the estimation of average values shown in Figure 3 for a 21-day window, from 10 days before to 10 days after the event day, we examine the 10-day window surrounding the press report. These daily ARs are then summed over the desired time period to calculate CAR. In particular, for the period from $t_{1}$ to $t_{2}$, CAR is calculated as follows:

$$
C A R_{t}=\sum_{k=t_{1}}^{t_{2}} A R_{i, k}
$$

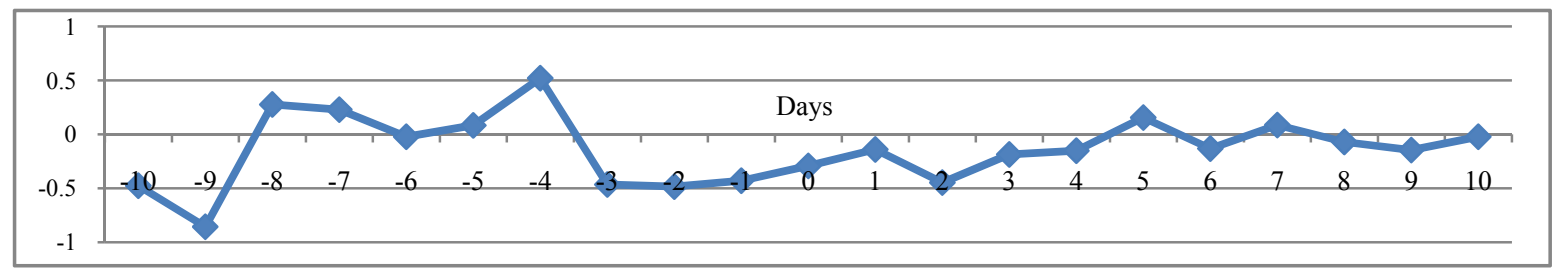

Figure 3. Transition of AR.

\section{Results for AR and CAR}

As shown in Figure 3, negative reactions continued through the period from day -3 to day +4 of the newspaper report day. To measure whether this result is statistically meaningful, we conduct a $t$-test and a non-parametric Wilcoxon signed-rank test (z-test). From Table 1, the market shows a statistically significantly negative reaction for 10 days, and especially, shows a significantly negative reaction at the level of $5 \%$ on day -3 and day -2 relative to event day. After event day, day +2 shows a significantly negative reaction at the level of $5 \%$.

Table 1

Result of AR Test

\begin{tabular}{rllll}
\hline AR & $N$ & Mean & $t$-statistic & $z$-statistic \\
\hline-10 & 50 & -0.465 & 1.5223 & $2.1189^{* *}$ \\
-9 & 50 & -0.732 & $2.9795^{* * *}$ & $3.0166^{* * *}$ \\
-8 & 50 & 0.332 & 1.5104 & 1.0184 \\
-7 & 50 & 0.146 & 0.6056 & 0.4103 \\
-6 & -0.035 & 0.1327 & 1.1246 \\
-5 & 50 & 0.049 & 0.2136 & 0.5551 \\
-4 & 50 & 0.426 & 1.5749 & 0.7192 \\
-3 & 50 & -0.357 & $1.7087^{*}$ & 1.3563 \\
-2 & 50 & -0.361 & $1.7233^{*}$ & 0.9895 \\
-1 & 50 & -0.331 & 1.4049 & 1.2694 \\
0 & 50 & -0.293 & 0.9841 & 1.1246 \\
1 & 50 & -0.127 & 0.5671 & 1.1825 \\
2 & 50 & -0.464 & $1.9841^{*}$ & $2.3023^{* *}$ \\
3 & 50 & -0.124 & 0.4025 & 0.2944 \\
4 & 50 & -0.139 & 0.6566 & 0.5165 \\
5 & 50 & 0.120 & 0.4260 & 0.1786 \\
6 & 50 & -0.229 & 1.0040 & 1.5204 \\
7 & 50 & 0.046 & 0.2444 & 0.4392 \\
8 & 50 & -0.052 & 0.2426 & 0.1014 \\
9 & 50 & -0.075 & 0.3572 & 1.1150 \\
10 & 50 & -0.118 & 0.6224 & 0.8833 \\
\hline$N o t e$ & 50 & 50.62 & \\
\hline
\end{tabular}

Note. $^{* * * * *},{ }^{* *}$ and ${ }^{*}$ indicate significance at the levels of $0.01,0.05$, and 0.10 (two-tailed test). 
We interpret this result of Table 1 as follows. We suppose that a tax inquiry, called a "notice of correction", is sent before the TPT news is released by JTA. In addition, we think that investors notice the delivery of the "notice of correction" by JTA before the news report, because the market reacts too negatively for three days immediately before the newspaper report. To test this conjecture, we analyze CAR by calculating it for different periods and identifying those for which there is a strong reaction. Untabulated results indicate that CARs for the proximate period around the news release date exhibit strong reactions.

\section{Hypotheses Development}

In Section 3, we perform an event study of how the market reacts to newspaper reports of TPT being applied and reveal that the capital market showed significant negative reactions to the newspaper reports. However, it is also necessary for us to think about how the financing information attribute of the company has an influence that might produce such a market reaction. We assume that the application of TPT is caused by lack of tax compliance and inadequacy of tax management. The company to which TPT was applied can be said to have weak CG. Therefore, we investigate what kinds of factors of the company trigger the reaction in the capital market for the newspaper report day and the following day.

To examine the association of application of TPT and market evaluation, it is necessary for us to rethink the cause of the reaction in the market. Stock market prices are based on future value discounted to the present value. In terms of evaluation, investors mainly regard information producing distrust about future prospects as negative information. The larger extent of information asymmetry between investors and managers is, the more negative reaction distrust of investors is raised.

Bushman, Chen, Engel, and Smith (2004) insisted that for companies for which transparency is lacking, to reduce the agency cost including a moral hazard issue, improvement of CG in the firm should be required. Hanlon, Mills, and Slemrod (2005) insisted that companies lacking compliance with respect to tax payment are large and this tendency is especially true in MNCs. In addition, Lassila, Omer, Shelley, and Smith (2010) insisted that the company tends to use a tax consulting service when a company's tax practice environment and organization are complicated. Thus, as the complexities of the organization increase, the amount of information asymmetry with the outside increases. This causes distrust in the company to increase, making it more likely to be evaluated negatively. Therefore, we set the following hypothesis:

H1: When the complexity of the organization increases, the market evaluates a company negatively because of the high information asymmetry between investors and the firm.

From the results shown in Figure 3, the reaction of the market to the application of TPT is negative. It is thought that the cause of such a reaction is distrust by investors. We expect that information asymmetry between investors and companies' managers produces a negative reaction in investors. As a cause of this asymmetry of information, Kato (2011) pointed out the existence of intangibles, saying that the market evaluates a company negatively when it holds many intangibles for which transparency is lacking. In particular, he took up the topic of research and development (R\&D) expenses that can be considered as the source of intangibles, asking whether the market evaluates an $R \& D$ expense negatively or not. Based on this point, we set the next hypothesis:

H2: When a company holds many intangibles and has high $R \& D$ expenses, the market evaluates it negatively because the company's transparency is low and information asymmetry is high. 
The cause of a market negative reaction is related to not only the uncertainties in TPT itself but also distrust in the company. Hanlon and Slemrod (2009) pointed out that when companies which are closely connected to consumers (B2C firms) use complicated schemes such as tax shelter and TP to reduce their tax burdens, they receive negative reactions from the market. When we think along this line, we recognize that companies who advertise do so partially to reduce their information asymmetry. Such companies tend to share information about the companies in order to avoid being distrusted. Moreover, Hanlon and Slemrod (2009) indicated that investors evaluate companies which bear high effective tax rates positively because investors judge such companies as good taxpayers having high tax compliance. So, if consumers have the same properties as investors, we can expect that the magnitude and level of companies' effective tax rates and their amounts of advertising investment are interrelated with their evaluations. Based on these points, we set the following hypotheses:

H3-1: For a company for which the rate of advertising investment is high, even if TPT is applied, the market reaction to this news is positive.

H3-2: For a company for which the effective tax rate is high, even if TPT is applied, the market reaction to this news is positive because the company is seen as conscientious regarding tax payment.

Executive compensation is expected to play a role in corporate value maximization through its incentive effect on managers. In a large company with separation of ownership from management, executive compensation becomes the core of the CG. With regard to executive compensation, the agency problem, which includes excess compensation, arises easily. On this point, Core, Holthausen, and Larcker (1999) suggested that executive compensation becomes excessive if $\mathrm{CG}$ is weak. Further, they pointed out the possibility that excessive executive compensation brings about adverse effects on corporate earnings later. In this regard, an application of TPT to a company can be considered as a sign that CG is not functioning sufficiently. The investors are more likely to judge the manager of such a company as monopolizing gain by using TP. Therefore, the market is expected to react negatively to such rent extraction.

On the other hand, Yamamoto and Sasaki (2010) reported that cash compensation, with the proof of good governance, leads to a positive market response starting in the following year. In other words, they suggested that through management compensation, Japanese companies have already been motivated to improve performance. As a result of the pursuit of corporate value maximization, companies to which TPT is applied have engaged in high-risk activities, that is, activities which might result in an investigation by JTA. In this regard, Ohnuma (2014) pointed out that executive compensation is determined in consideration of the high-risk duties taken on by manages, such as tax avoidance activity and the degree of CG. In other words, in a company where CG functions properly, when determining the executive compensation, the bonding of the managers with their firms reflects on the corporate value maximization. We hypothesize that companies with strong CG rarely have TPT applied and do not make excessive executive compensation decisions. In this regard, we set the following hypotheses:

H4-1: As executive compensation increases, assumptions of rent extraction by the manager strengthen and the market reacts negatively.

H4-2: As executive compensation increases, assumptions of the bonding of the manager strengthen and the market reacts positively. 


\section{Research Design}

Section 3 uses newspaper reports about applications of TPT. In terms of financial data, we collect the consolidated financial statements data from Nikkei NEEDS Financial Quest (FQ) 2.0 and use data in the accounting period just before the newspaper report. Because one company is excluded on account of the unavailability of data, in this analysis, we analyze 50 examples, the same as in the analysis of AR and CAR in Section 3. Here, information that is not available is handled as missing data. In building the research design, we adopt CAR $(0,1)$ as the dependent variable. On the basis of the survey by Cavusoglu et al. (2004), we estimate that information about a TPT given by a newspaper report spreads completely through the markets by the end of the day after event day. A multiple linear regression model, given in Equation (4), is set up to study the relationship between CARs and characteristics of events. With a multiple regression analysis, we use the following model based on Hanlon and Slemrod (2009):

$$
\begin{aligned}
& \text { CAR }_{i, t}=\beta_{0}+\beta_{1} \ln _{-} \text {Subsidiary }_{i, t}+\beta_{2} \text { Foreignsales }_{i, t}+\beta_{3} \text { Manufact }_{i, t}+\beta_{4} \text { Intangibles }_{i, t_{i, t}}
\end{aligned}
$$

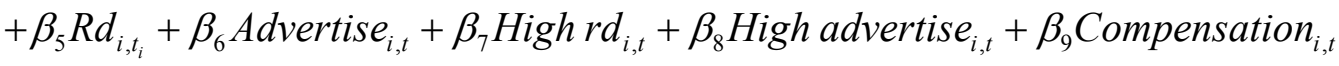

$$
\begin{aligned}
& +\beta_{10} \text { Leverage }_{i, t}+\beta_{11} \text { Current_rate }_{i, t}+\beta_{12} \text { Interestcoverage }_{i, t} \\
& +\beta_{13} \operatorname{LosS}_{i, t}+\beta_{14} T_{A X} X_{i, t}+\varepsilon_{i, t} \\
& \text { ETR, Current_ETR } \in \text { Tax }
\end{aligned}
$$

Definitions of each variable are described in Table A1 in Appendix A.

To examine H1, as a factor to represent the complexity of the company organization, we use logarithm of the number of subsidiaries ln_Subsidiary, ratio of overseas sales Foreignsales, and manufacturing industry dummy variable Manufact. With regard to the predictive sign, we expect $\beta_{1}<0, \beta_{2}<0$, and $\beta_{3}<0$ to hold, based on $\mathrm{H} 1$; however, since the ratio of overseas sales indicates the potential for future growth, we expect $\beta_{2}>0$.

To examine $\mathrm{H} 2$, as a factor causing a lack of transparency, we use intangible-fixed-assets-to-sales ratio Intangibles and R\&D-to-sales ratio $R d$. Regarding the predictive sign, we expect $\beta_{4}<0$ and $\beta_{5}<0$.

To examine $\mathrm{H} 3$, as a factor causing the transparency increase, we use advertising-to-sales ratio Advertise. In addition, following Hanlon and Slemrod (2009), we set dummy variables for the company being higher than the overall median. Specifically, we set the High $r d$ and High advertise variables as 1 for companies which are higher than the median and 0 if otherwise. With regard to the predictive sign, we expect $\beta_{6}>0, \beta_{7}<0$, and $\beta_{8}>0$.

To examine H4, we use executive compensation Compensation as a proxy variable in order to inspect whether CG is functioning well. With regard to the predictive sign, we expect $\beta_{9} \neq 0$. In addition, we use, as a control variable, long-term debt to total asset ratio Leverage, Current_rate, interest coverage ratio Interestcoverage, and loss carried forward Loss_dummy. For the predictive sign, because this evaluation is of safety as perceived by investors, we expect $\beta_{10} \neq 0, \beta_{11} \neq 0$, and $\beta_{12} \neq 0$. Since Loss_dummy measures the extent that corporate performance has not been good in the past fiscal year and is taken as a minus to corporate performance in the future by the market, we expect $\beta_{13}<0$.

To examine the relationship between the variable $T A X$, which indicates the status of the tax burden and the reaction of investors, we use effective tax rate ETR for the company and cash tax rate Cash_ETR.

When $\mathrm{H} 3$ is assumed, we expect $\beta_{14}>0$. Descriptive statistics of data are listed in Table 2. 
Table 2

Descriptive Statistics

\begin{tabular}{lllllc}
\hline Variable & Obs. & Mean & Std. dev. & Min. & Max. \\
\hline CAR $(0,1)$ & 50 & -0.4191 & 2.9220 & -7.1652 & 7.7796 \\
In_Subsidiary & 50 & 4.6147 & 1.3311 & 1.6094 & 6.9546 \\
Foreignsales & 50 & 0.4646 & 0.2740 & 0.0000 & 0.8988 \\
Manufact & 50 & 0.7400 & 0.4431 & 0.0000 & 1.0000 \\
Intangibles & 50 & 0.0272 & 0.0486 & 0.0000 & 0.3045 \\
Rd & 50 & 0.0423 & 0.0459 & 0.0000 & 0.2221 \\
Advertise & 50 & 0.0152 & 0.0266 & 0.0000 & 0.1043 \\
Highrd & 50 & 0.8600 & 0.3505 & 0.0000 & 1.0000 \\
High advertise & 50 & 0.5400 & 0.5035 & 0.0000 & 1.0000 \\
Compensation & 50 & 0.0004 & 0.0010 & 0.0000 & 0.0061 \\
Leverage & 50 & 0.6948 & 0.7985 & 0.0000 & 3.3952 \\
Current_rate & 50 & 1.6011 & 1.1105 & 0.3177 & 4.7812 \\
Interestcoverage & 50 & 1.1019 & 1.9588 & 0.0306 & 10.9080 \\
Loss_dummy & 50 & 0.0400 & 0.1979 & 0.0000 & 1.0000 \\
ETR & 50 & 0.3825 & 0.1190 & 0.0000 & 0.6022 \\
Cash_ETR & 50 & 0.3543 & 0.1498 & 0.0000 & 0.6960 \\
Size & 50 & 14.1314 & 1.7242 & 9.2823 & 16.3035 \\
Capital_intensity & 50 & 12.4784 & 1.7061 & 7.7075 & 14.6057 \\
\hline
\end{tabular}

Table 3 lists the correlations among variables. The bottom half gives Pearson correlation coefficients and the top half gives Spearman correlation coefficients. As shown, strong correlations among the number of the subsidiaries, fixed asset ratio Capital_intensity, and Size (the logarithm of total assets book value, which is a proxy variable for the corporate scale) reveal on this table.

Therefore, it is necessary for us to take these correlations into consideration in this analysis.

Without any adjustments for Equation (4), it is concerned with the endogeneity problem. Parameter estimates from OLS, for example, will be biased when the regressors are endogenously determined along with the dependent variable. Actually, Equation (5) in the two-equation system allows us to assess whether in the cross-section, there is a positive association among Capital_intensity, Size, and $\ln$ _Subsidiary while also controlling for other factors that previous literature has shown to influence size effect. Equation (5) below models an organizational complexity and is included to control for the endogeneity of size effect and investment opportunity in examining market reaction to managers' behaviors:

$$
\begin{gathered}
\ln \_ \text {Subsidiary }_{i}=\alpha_{0}+\alpha_{1} \text { Foreignsales }_{i, t}+\alpha_{2} \text { Manufact }_{i, t}+\alpha_{3} \text { Intangibles }_{i, t} \\
+\alpha_{4} \text { Rd }_{i, t}+\alpha_{5} \text { Advertise }_{i, t}+\alpha_{6} \text { High rd }_{i, t}+\alpha_{7} \text { High advertise }_{i, t}+\alpha_{8} \text { TAX }_{i, t} \\
+\alpha_{9} \text { Compensation }_{i, t}+\alpha_{10} \text { Leverage }_{i, t}+\alpha_{11} \text { Current_rate }_{i, t}+ \\
\alpha_{12} \text { Interestcoverage }_{i, t}+\alpha_{13} \text { Loss_dummy }_{i, t}+\alpha_{14} \text { Size }_{i, t} \\
+\alpha_{15} \text { Capital_intensity }_{i, t}+\varepsilon_{i, t} \\
\text { ETR,Current_ETR } \in \text { Tax }
\end{gathered}
$$

Similar to Rajgopal and Shevlin (2002) and Coles, Daniel, and Naveen (2006), we use two-stage least squares to estimate our simultaneous system of equations, where proxies for market reaction to TPT and organizational complexity are the endogenous, dependent variables. 


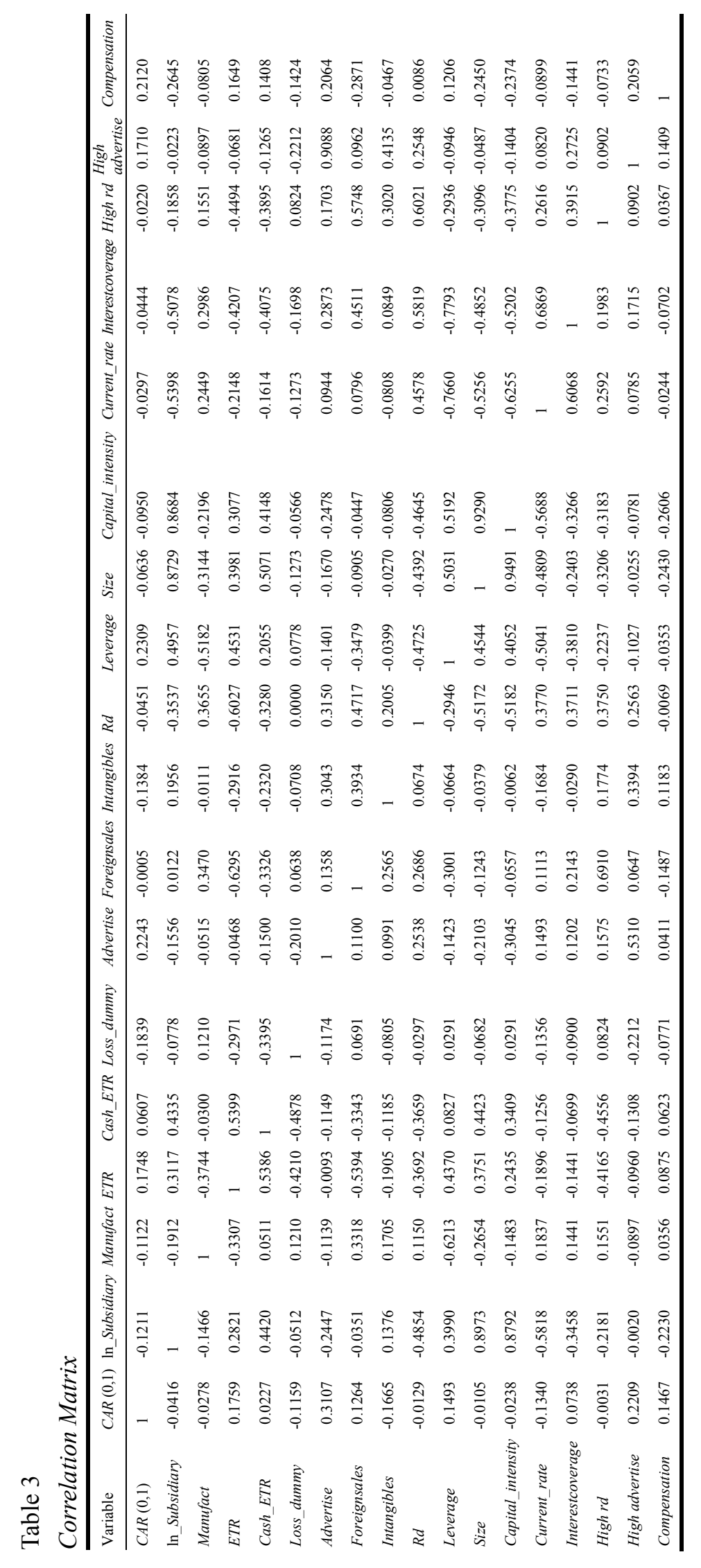




\section{Results of Analysis}

Results of regression analysis using the least-squares method are shown in Tables 4 and 5. Table 4 adopts ETR as the TAX variable, whereas Table 5 adopts Cash_ETR as the TAX variable. In both cases, to deal with heterogeneous dispersion of the error term, we handle the standard error based on the method of White (1980). The result of every model is shown in each table, and all models have high explanatory power.

With respect to H1, the number of subsidiaries ( $\ln \_$Subsidiary) is almost significantly negative. Organizations with higher complexity are more poorly evaluated by investors because of information asymmetry between inside and outside the company. On the other hand, CAR is high when the companies extend overseas business positively and the ratio of overseas sales is high. For companies to which TPT is applied, the ratio of overseas sales is, on average, approximately $50 \%$; because the companies are expected to continue developing overseas in the future, their evaluation is high. Thus, merely having high organizational complexity does not make the evaluations fall, even if such companies' organizations are complicated. Besides, we find that the investors do not lower the evaluation of such a company even if they develop overseas business for the potential growth. At the same time, from leverage (Leverage) being almost significantly positive in all panels, leverage is evaluated positively in a market as that the company is actively working towards tax savings.

With respect to H2, interpretation of intangibles (Intangibles) is difficult. Because transparency with the outside decreases with increasing intangibles, it is easy for distrust to arise in the case of the application of TPT. Intangible fixed assets on the balance sheet are almost significantly negative. On the other hand, the $\mathrm{R} \& \mathrm{D}$-to-sales ratio $(R d)$ is not significant. Although intangible fixed assets on the balance sheet are almost significantly negative, companies to which TPT is applied may not be invested in the market due to lack of transparency.

Table 4

Results With ETR as the TAX Variable

\begin{tabular}{|c|c|c|c|c|c|c|c|c|c|}
\hline \multirow{2}{*}{ Variable } & \multirow{2}{*}{$\begin{array}{l}\text { Predicted } \\
\text { sign }\end{array}$} & \multicolumn{2}{|c|}{ Model 1} & \multicolumn{2}{|c|}{ Model 2} & \multicolumn{2}{|c|}{ Model 3} & \multicolumn{2}{|c|}{ Model 4} \\
\hline & & Coef. & $z$ & Coef. & $z$ & Coef. & $z$ & Coef. & $z$ \\
\hline ln_Subsidiary & - & -0.793 & $-1.88^{*}$ & -0.548 & -1.45 & -0.9312 & $-2.01^{* *}$ & -1.031 & $-2.52^{* *}$ \\
\hline Foreignsales & $+/-$ & 5.187 & $2.70^{* * *}$ & 3.660 & $2.66^{* * *}$ & & & & \\
\hline Manufact & - & 1.627 & 1.52 & 1.742 & 1.63 & 1.346 & 1.34 & 1.429 & 1.43 \\
\hline Intangibles & - & -22.735 & $-5.44^{* * *}$ & -23.389 & $-5.4^{* * *}$ & -23.011 & $-5.8^{* * *}$ & -22.35 & $-5.69^{* * *}$ \\
\hline$R d$ & - & -8.623 & -0.99 & 1.164 & $2.42^{* *}$ & -8.075 & -0.85 & -9.164 & -1.05 \\
\hline Advertise & + & 22.584 & 1.41 & 23.204 & 1.37 & 5.718 & $3.05^{* * *}$ & 5.416 & $2.82^{* * *}$ \\
\hline High rd & - & -1.381 & -1.11 & & & -1.353 & -1.07 & -1.130 & -0.90 \\
\hline High advertise & + & 1.748 & $1.97^{* *}$ & 1.535 & $1.69^{*}$ & 2.428 & $2.82^{* * *}$ & 2.529 & $3.07^{* * *}$ \\
\hline Compensation & + & 363.297 & 1.28 & 366.112 & 1.37 & 300.307 & 1.03 & & \\
\hline Leverage & $+/-$ & 1.247 & $2.58^{* *}$ & & & 1.069 & $2.21^{* *}$ & 1.063 & $2.2^{* *}$ \\
\hline Current_rate & $+/-$ & -0.999 & $-2.42^{* *}$ & -1.059 & $-2.90^{* * *}$ & -1.022 & $-2.46^{* *}$ & -1.087 & $-2.77^{* * *}$ \\
\hline Interestcoverage & $+/-$ & 0.003 & 1.27 & 0.003 & 1.43 & 0.003 & 1.07 & 0.003 & 1.01 \\
\hline Loss_dummy & - & -0.949 & -0.63 & -0.959 & -0.59 & -0.560 & -0.37 & -0.653 & -0.44 \\
\hline ETR & + & 5.697 & $1.72^{*}$ & 6.074 & $1.70^{*}$ & 7.468 & $2.11^{* *}$ & 7.755 & $2.13^{* *}$ \\
\hline Intercept & $?$ & -1.336 & -0.44 & -3.253 & -1.31 & -1.268 & -0.39 & -0.827 & -0.27 \\
\hline Wald & & $75.58^{* * *}$ & & $61.63^{* * *}$ & & $75.93^{* * *}$ & & $66.36^{* * *}$ & \\
\hline$R$-squared & & 0.4317 & & 0.4136 & & 0.4022 & & 0.3908 & \\
\hline
\end{tabular}

Note. $^{* * * * *},{ }^{* *}$ and ${ }^{*}$ indicate significance at the levels of $0.01,0.05$, and 0.10 (two-tailed test). 
Table 5

Results With Cash ETR as the TAX Variable

\begin{tabular}{|c|c|c|c|c|c|c|c|c|c|}
\hline \multirow{2}{*}{ Variable } & \multirow{2}{*}{$\begin{array}{l}\text { Predicted } \\
\text { sign }\end{array}$} & \multicolumn{2}{|c|}{ Model 1} & \multicolumn{2}{|c|}{ Model 2} & \multicolumn{2}{|c|}{ Model 3} & \multicolumn{2}{|c|}{ Model 4} \\
\hline & & Coef. & $z$ & Coef. & $z$ & Coef. & $z$ & Coef. & $z$ \\
\hline ln_Subsidiary & - & -0.663 & -1.10 & -0.415 & -0.66 & -0.932 & -1.45 & -1.073 & $-2.04^{* *}$ \\
\hline Foreignsales & $+/-$ & 4.078 & $2.30^{* *}$ & 2.644 & $1.78^{*}$ & & & & \\
\hline Manufact & - & 1.791 & 1.64 & 1.842 & $1.65^{*}$ & 1.333 & 1.32 & 1.354 & 1.33 \\
\hline Intangibles & - & -24.046 & $-5.69^{* * *}$ & -24.535 & $-5.46^{* * *}$ & -24.265 & $-5.61^{* * *}$ & -23.377 & $-5.47^{* * *}$ \\
\hline$R d$ & - & -10.493 & -1.18 & & & -10.539 & -1.03 & -11.585 & -1.22 \\
\hline Advertise & + & 28.730 & $1.72^{*}$ & 29.302 & 1.62 & 4.508 & $2.54^{* *}$ & 4.229 & $2.32^{* *}$ \\
\hline High rd & - & -1.270 & -0.97 & & & -1.016 & -0.70 & -0.715 & -0.53 \\
\hline High advertise & + & 1.452 & 1.51 & 1.228 & 1.27 & 2.373 & $2.59^{* * *}$ & 2.508 & $2.97^{* * *}$ \\
\hline Compensation & + & 428.513 & 1.19 & 439.512 & 1.28 & 313.793 & 0.84 & & \\
\hline Leverage & $+/-$ & 1.523 & $3.37^{* * *}$ & 1.457 & $3.36^{* * *}$ & 1.406 & $3.15^{* * *}$ & 1.413 & $3.21^{* * *}$ \\
\hline Current_rate & $+/-$ & -0.997 & $-2.37^{* *}$ & -1.044 & $-2.80^{* * *}$ & -1.063 & $-2.34^{* *}$ & -1.137 & $-2.67^{* * *}$ \\
\hline Interestcoverage & $+/-$ & 0.004 & 1.47 & 0.003 & 1.58 & 0.003 & 1.26 & 0.003 & 1.19 \\
\hline Loss_dummy & - & -2.333 & -1.64 & -2.168 & -1.39 & -1.772 & -1.48 & -1.647 & -1.47 \\
\hline Cash_ETR & + & 0.088 & 0.02 & 0.727 & 0.18 & 1.905 & 0.50 & 2.707 & 0.84 \\
\hline Intercept & $?$ & 0.477 & 0.18 & -1.548 & -0.72 & 1.195 & 0.43 & 1.596 & 0.63 \\
\hline Wald & & $81.7^{* * *}$ & & $64.46^{* * *}$ & & $91.66^{* * *}$ & & $89.09^{* * *}$ & \\
\hline$R$-squared & & 0.4174 & & 0.3945 & & 0.3693 & & 0.357 & \\
\hline
\end{tabular}

Note. ${ }^{* * *},{ }^{* *}$, and $^{*}$ indicate significance at the levels of $0.01,0.05$, and 0.10 (two-tailed test).

With respect to $\mathrm{H} 3$, companies with high advertising investments and high effective tax rates are evaluated positively in the market. Although an application of TPT causes distrust by investors, we assume that investors also evaluate the activeness of information disclosure of companies with high advertising investments. Similarly, as Hanlon and Slemrod (2009) indicated that because the companies with high effective tax rates are considered to be good corporate citizens, they are evaluated positively. Advertising investment creates brand awareness by an active disclosure of company information, and advertising investment enhances a company's reputation as a good corporate citizen and contributes to raising transparency. Investors evaluate the application of TPT negatively, but from this evidence as well as that of Hanlon and Slemrod (2009), we think that investors evaluate a company engaging in advertising investment and making appropriate tax payments positively.

With respect to $\mathrm{H} 4$, when a market reacts to an executive compensation (Compensation) negatively, the market is suspecting whether the manager extracts rents or not. In consideration of the above, the reaction of the market to executive compensation is not consistent among models, but we interpret the results as that the market reacts to executive compensation positively. Of course, when TPT is applied to a company, it is difficult to claim that $\mathrm{CG}$ functions well, but from that, the market shows a positive reaction to executive compensation; we suggest that investors are less likely to suspect the manager of rent extraction.

\section{Conclusions and Suggested Future Work}

This paper examines how the market evaluates news of TPT by investigating the market reaction to an initial press report mentioning that a firm was involved in a TP manipulation and tax underpayment.

As a result of event study analysis, we find that the capital market shows a statistically significant negative reaction to newspaper reports of the application of TPT. The market shows a significantly negative reaction for a total of 10 days and shows a significantly negative reaction at the level of $5 \%$ for three days. 
Next, we carry out a multiple regression analysis of AR and sum the daily AR over a given time period to calculate CAR. Using CAR as a dependent variable, we then perform a multiple regression analysis to identify the source of market reactions. The results indicate that the number of subsidiaries, ratio of overseas sales, intangible fixed assets on the balance sheet, advertising-to-sales ratio, and effective tax rate are statistically significant. The market shows a positive reaction to variables strongly related to the future and the transparency of the company, such as the ratio of overseas sales and advertising-to-sales ratio, or variables suggesting compliance, such as effective tax rate. In contrast, the market shows a negative reaction to variables that indicate intensity of information asymmetry, such as the number of subsidiaries and amount of intangible fixed assets on the balance sheet. In addition, we think that the suspicion of rent extraction by the manager, which Hanlon and Slemrod (2009) suggested, does not fit our sample, based on the reaction of investors to the advertising-to-sales ratio and executive compensation. From these results, we suspect that Leverage, which is used as a proxy variable for legal tax reduction activity, is not appropriate for this analysis.

In future work, we need to investigate further what causes market reactions. Similarly, we need to analyze what types of intangible fixed assets the market reacts to.

\section{References}

Armstrong, C. S., Barth, M. E., Jagolinzer, A. D., \& Riedl, E. J. (2010). Market reaction to the adoption of IFRS in Europe. The Accounting Review, 85(1), 31-61.

Bankman, J. (2004). An academic's view of the tax shelter battle. In H. J. Aaron \& J. Slemrod (Eds.), The crisis in tax administration. Washington DC: Brookings Institution.

Bushman, R., Chen, Q., Engel, E., \& Smith, A. (2004). Financial accounting information, organizational complexity, and corporate governance systems. Journal of Accounting and Economics, 37(2), 167-201.

Campbell, K., Gordon, L. A., Loeb, M. P., \& Zhou, L. (2003). The economic cost of publicly announced information security breaches: Empirical evidence from the stock market. Journal of Computer Security, 11(3), 431-448.

Cavusoglu, H., Mishra, B., \& Raghunathan, S. (2004). The effect of internet security breach announcements on market value: Capital market reactions for breached firms and internet security developers. International Journal of Electronic Commerce, 9(1), 69-104.

Chen, S., Chen, X., Cheng, Q., \& Shevlin, T. (2010). Are family firms more tax aggressive than non-family firms? Journal of Financial Economics, 95(1), 41-61.

Coles, J. L., Daniel, N. D., \& Naveen, L. (2006). Managerial incentives and risk-taking. Journal of Financial Economics, 79(2), 431-468.

Core, J., Holthausen, R. W., \& Larcker, D. F. (1999). Corporate governance, chief executive officer compensation, and firm performance. Journal of Financial Economics, 51(3), 371-406.

Croyd, C. B., Mills, L., \& Weaver, C. D. (2003). Firm valuation effects of the expatriation of U.S. corporations to tax-haven countries. Journal of American Taxation Association, 25, 87-109.

Desai, M. A., \& Dharmapala, D. (2006). Corporate tax avoidance and high powered incentives. Journal of Financial Economics, 79(1), 145-179.

Fama, E., \& French, K. R. (1992). The cross-section of expected stock returns. Journal of Finance, 47(2), 427-465.

Gatzlaff, K. M., \& McCullough, K. A. (2010). The effect of data breaches on shareholder wealth. Risk Management and Insurance Review, 13(1), 61-83.

Ghosh, C., Giambona, E., Harding, J., Sezer, O., \& Sirmans, C. F. (2010). The role of managerial stock option programs in governance: Evidence from REIT stock repurchases. Real Estate Economics, 38(1), 31-55.

Graham, J., \& Tucker, A. (2006). Tax shelters and corporate debt policy. Journal of Financial Economics, 81(3), $563-594$.

Hanlon, M., \& Slemrod, J. (2009). What dose tax aggressiveness signal? Evidence from stock price reactions to news about tax shelter involvement. Journal of Public Economics, 93(1-2), 126-141.

Hanlon, M., Mills, L., \& Slemrod, J. (2005). An empirical examination of corporate tax noncompliance. Working Paper, Sloan School of Management, Massachusetts Institute of Technology. 
Japan Taxation Agency [JTA]. (2013). The situation of the advance pricing agreement. Retrieved from http://www.nta.go.jp/kohyo/press/press/2013/sogo_kyogi/pdf/01.pdf (in Japanese)

Kato, K. (2011). The reaction of the capital market to the transfer pricing taxation system: An analysis of taxation information on intangible assets. Studies in the Humanities, 26, 73-87 (in Japanese).

Lassila, D. R., Omer, T. C., Shelley, M. K., \& Smith, L. M. (2010). Do complexity, governance, and auditor independence influence whether firms retain their auditors for tax services? Journal of the American Taxation Association, 32(1), 1-23.

Lee, K., \& Joso, Y. (2009). The investigation of Japanese company international transfer price. Melco Journal of Management Accounting Research, 2, 111-126 (in Japanese).

Ohnuma, H. (2014). Does executive compensation reflect equity risk incentives and corporate tax avoidance? A Japanese perspective. Corporate Ownership and Control, 11(2), 60-71.

Onuma, H. (2011). The voluntary disclosure and influence of substantial effect on measurement of the IR about the transfer price taxation. Japan IR Association. Final Report on a Special Study Committee: 177-1908 (in Japanese).

Rajgopal, S., \& Shevlin, T. (2002). Empirical evidence on the relation between stock option compensation and risk taking. Journal of Accounting and Economics, 33(2), 145-171.

Sharma, R., \& Mehta, K. (2013). Fama and French: Three factor model. SCMS Journal of Indian Management, 10(2), 90-105.

Tang, R. Y. W. (1992). Transfer pricing in the 1990's: Tax and management perspectives. Westport, CT: Quorum Book.

White, H. (1980). A heteroskedasticity-consistent covariance matrix estimator and a direct test for heteroskedasticity. Econometrica, 48(4), 817-838.

Yamamoto, S., \& Sasaki, T. (2010). Corporate governance and management compensation. Securities Analyst Journal, 48(6), 34-43 (in Japanese).

\section{Appendix A}

Table A1

Variable Definitions

\begin{tabular}{|l|l|}
\hline Variable & Definition \\
\hline CAR & Cumulative abnormal return \\
\hline In_Subsidiary & Natural log of the number of subsidiaries \\
\hline Foreignsales & Sales in foreign countries divided by total sales \\
\hline Manufact & An indicator variable which equals to 1 if the firm belongs to the manufacturing industries and 0 if otherwise \\
\hline Intangibles & Intangible fixed assets divided by total sales \\
\hline Rd & Research and development expense divided by total sales \\
\hline Advertise & Advertisement expense divided by total sales \\
\hline High rd & $\begin{array}{l}\text { An indicator variable which equals to } 1 \text { if companies' R\&D expense is higher than the median in the } \\
\text { sample and } 0 \text { if otherwise }\end{array}$ \\
\hline High advertise & $\begin{array}{l}\text { An indicator variable which equals to } 1 \text { if companies' advertising expense is higher than the median in the } \\
\text { sample and 0 if otherwise }\end{array}$ \\
\hline Compensation & $\begin{array}{l}\text { Total amount of compensation including cash, bonus, and postretirement paid for the executive directors in } \\
\text { the companies divided by total sales }\end{array}$ \\
\hline Leverage & Total long-term debt scaled by beginning-of-year total assets \\
\hline Current_rate & Current asset minus inventory scaled by current liability \\
\hline Interestcoverage & $\begin{array}{l}\text { Company's earnings before interest and taxes (EBIT) of one period divided by the company's interest } \\
\text { expenses of the same period }\end{array}$ \\
\hline Loss_dummy & An indicator variable which equals to 1 if net income at $t$ is negative and 0 if otherwise \\
\hline TAX & ETR and Cash_ETR \\
\hline ETR & Effective tax rate, defined as total tax expense divided by pre-tax book income less special items \\
\hline Cash_ETR & Cash effective rate, defined as cash taxes paid divided by pre-tax book income less special items \\
\hline
\end{tabular}

